\title{
Socioeconomic and health characteristics of older adults cared for by a multiprofessional family health team
}

\author{
Características socioeconômicas e de saúde de idosos \\ assistidos pela estratégia saúde da família e por \\ uma equipe de residência multiprofissional
}

Tatiana Silveira Marzola ${ }^{[a]}$, Maycon Sousa Pegorari ${ }^{[b]}$, Lislei Jorge Patrizzi ${ }^{[a]}$, Suraya Gomes Novais-Shimano ${ }^{[\mathrm{a}]^{*}}$

[a] Universidade Federal do Triângulo Mineiro (UFTM), Uberaba, MG, Brazil

[b] Universidade Federal do Amapá (UNIFAP), Macapá, AP, Brazil

\begin{abstract}
Introduction: Population aging may give rise to a greater burden of diseases and disabilities, leading to the greater use of health services and the need for studies of the aged population. Health care teams and specialized residency programs constitute a strategy for the monitoring of older adults' health status. Objective: To investigate the socioeconomic profile and health status of older adults in different age groups cared for by a multiprofessional family health team. Methods: This cross-sectional, quantitative study was conducted with 249 older adults registered in a Family Health Strategy (FHS) program in Uberaba, MG, Brazil. Socioeconomic and health status data were collected through home interviews using a structured questionnaire. Chi-square analysis was used for descriptive and bivariate analyses $(p<0.05)$. Results: Most older adults aged 60-70 years were functionally independent, married and had a mean monthly income of 1-3 times the Brazilian minimum wage. Older adults aged 70 - 79 years made use of 1 - 3 medications and had morbidities such as depression, cataract and glaucoma. There was a greater proportion of illiterates
\end{abstract}

* TSM: MS, e-mail: tathysi@hotmail.com

MSP: MS, e-mail: mayconpegorari@yahoo.com.br

LJP: PhD, e-mail: lpatrizzi@uol.com.br

SGNS: PhD, e-mail: surayagnovais@hotmail.com 
in the age group 80 years or over. Conclusion: Socioecnomic and health status were associated with age groups. Of note, there was a higher prevalence of medication use and morbidities among older adults aged $70-79$ years. The knowledge of these characteristics helps FHS team members to implement more accurate and customized strategies and interventions to deliver more effective and efficient care to older adults. Moreover, participation in a multiprofessional team provides an interdisciplinary learning and work experience for health professionals.

Keywords: Older Adults. Health Profile. Family Health. Professional Competence.

\section{Resumo}

Introdução: $O$ envelhecimento populacional pode conferir maior carga de doenças, incapacidades e uso dos serviços de saúde, aspectos que sugerem a necessidade de investigações a partir do contexto populacional observado; e a equipe de saúde e os programas de residências constituem estratégia no monitoramento das condições de saúde do idoso. Objetivo: Analisar o perfil socioeconômico e condições de saúde de idosos assistidos pela estratégia saúde da família e por uma equipe residência multiprofissional em diferentes faixas etárias. Métodos: Estudo transversal e quantitativo, conduzido com 249 idosos cadastrados numa ESF em Uberaba, MG. Foram realizadas entrevistas domiciliares a partir de questionário estruturado com informações socioeconômicas e de saúde. Procedeu-se às análises descritiva e bivariada por meio do teste qui-quadrado $(p<0,05)$.

Resultados: A maior proporção de idosos na faixa etária de 60 a 70 anos eram independentes funcionalmente, casados e com renda de 1 a 3 salários mínimos. Idosos com 70 a 79 anos apresentaram uso de 1 a 3 medicamentos e morbidades como depressão, catarata e glaucoma; enquanto naqueles com 80 anos e mais, maior proporção de analfabetos. Conclusão: As condições econômicas e de saúde foram associadas às faixas etárias, com destaque para a maior proporção de idosos entre 70 a 79 anos no que se refere ao uso de medicamentos e presença de morbidades. Essas características permitem à equipe implementar estratégias e intervenções, mais precisas e pontuais, buscando atender os idosos de forma mais efetiva e eficaz; além de proporcionar ao residente aprendizagem e experiência no trabalho interdisciplinar.

Palavras-chave: Idoso. Perfil de Saúde. Saúde da Família. Competência Profissional.

\section{Introduction}

Population aging is a major challenge in contemporary public health (1). In Brazil, changes in the population's age structure are occurring in a rapid and extreme fashion, resulting in a greater prevalence of age-related diseases and disabilities and increased use of health services (2). According to the Brazilian National Health Policy for Older Adults, among other things, this indicates the need for the "ongoing training and education of Unified Health System (SUS) professionals on older people's health needs" (3).

Hence, interdisciplinary health residency programs created since the promulgation of Law No.11.129 (2005) are guided by SUS principles and guidelines, in accordance with local and regional needs and realities. Among the basic guidelines contemplated in the Brazilian Interministerial Ordinance MEC / MS No. 1077 of November 12th, 2009, we highlight Article 2nd: I - health education in representative (national) social and epidemiological settings; VI - integration between education, service and community through partnership programs with managers, workers and health service users; XII comprehensive care in all health care levels as well as comprehensive management of the system (4).

Therefore, it is believed that the integration between a multiprofessional health residency and the Family Health Strategy (FHS) program may constitute a major strategy for the treatment of older people. To this end, functional capacity maintenance, health status monitoring, preventive and differentiated health and education actions, and comprehensive quality and multidimensional care should be considered as priorities (2). In addition, 
knowledge of the social, economic, cultural, demographic and epidemiological characteristics can be helpful in implementing local strategies to address any identified health problems and risk situations (5).

Given the above, this study aimed to investigate the socioeconomic profile and health status of older adults in different age groups cared for by a multiprofessional family health team, in order to use the knowledge of this population's characteristics to implement more effective and efficient interdisciplinary health interventions.

\section{Methods}

This was a cross-sectional, analytical, descriptive, observational, quantitative study.

The study population was composed of older adults registered in a FHS program in Uberaba, MG, Brazil. Information on the study sample (such as family registers, housing and sanitation conditions, health status, work and composition of health care teams) was obtained from the Basic Care Information System (SIAB) (6). We found that 540 older adults were registered in the FHS program of the city of Uberaba.

The data were collected during three months at the older adults' homes, which were locatedin the urban area of Uberaba, MG, Brazil. The study included adults aged 60 years or older, who agreed to participate in the study and gave written informed consent or had signed consent provided by appropriate relatives. The exclusion criteria were older adults who: 1) could not be located after three visits at different times; 2) had moved address; 3 ) had provided a "ghost address"; and 4) had died.

Of a total number of 540 older adults registered in the FHS program, 249 were interviewed in this study. Figure 1 is a flowchart depicting the study population, exclusion and/or losses of participants; and the total number of older adults interviewed.

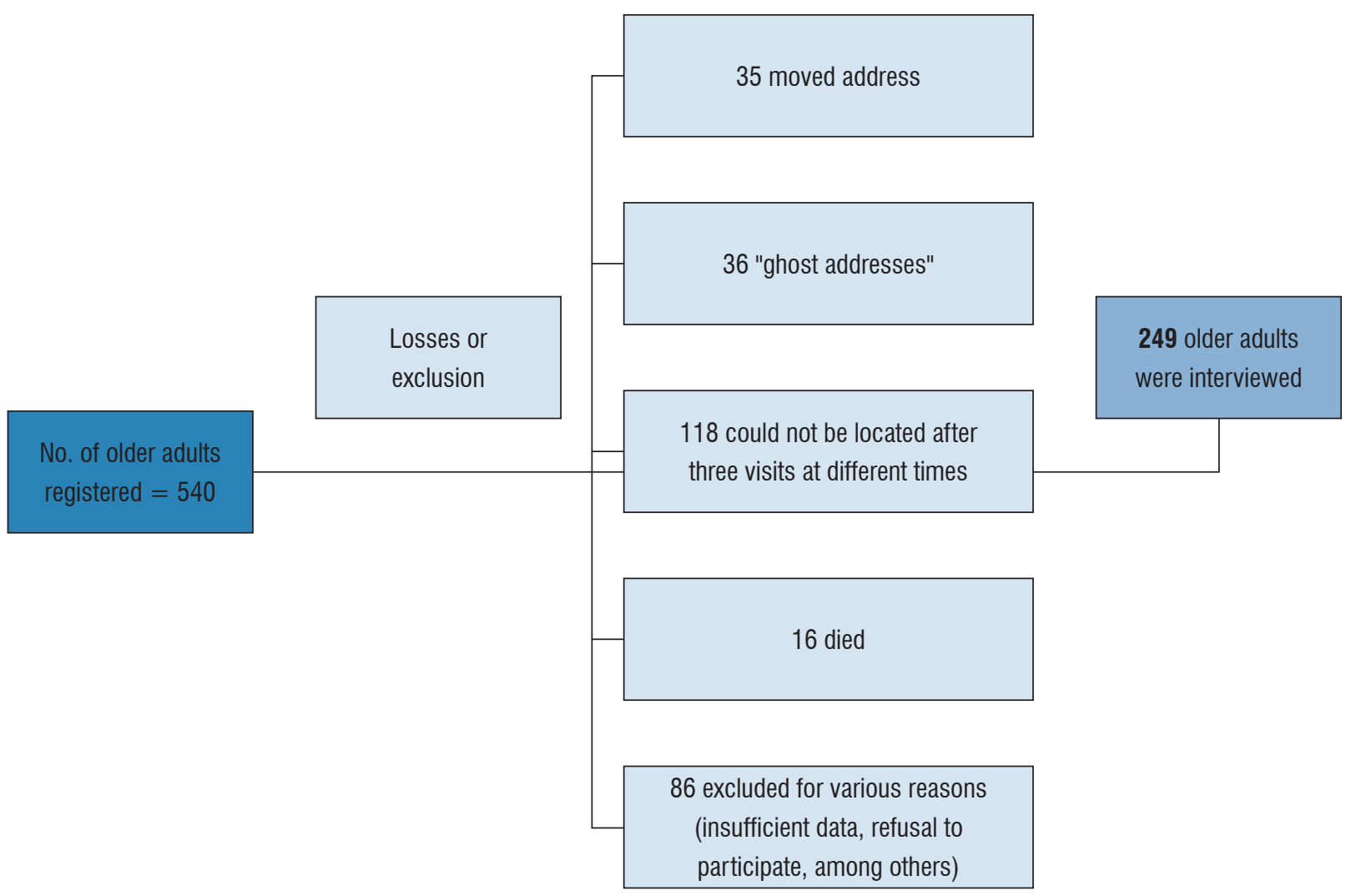

Figure 1 - Study population flowchart. 
Data were collected through home interviews using a structured questionnaire on socioeconomic and health status, based on the guidelines of the "Linha Guia de Atenção à Saúde do Idoso (guidelines on the provision of care to older adults, Secretaria de Estado de Saúde de Minas Gerais, 2006) (7) and the "Caderneta de Saúde da Pessoa Idosa" (8).

The following variables were assessed: gender (male/female), age group (60ト70, $70 \vdash 80$ and 80 or older), marital status (single, married, widowed, divorced, consensual union) consensual), monthly income (1 time the [Brazilian] minimum wage [MW], $1 \dashv 3$ times the MW, 3 or more times the MW), education (illiterate, $1 \dashv 4$ years, $4 \dashv 8$ years, 8 or more years), responsible for household expenses (yes / no), number of morbidities (none, 1, 2 or more), number of medications used (none, $1 \vdash 3,3 \vdash 5$, 5 or more), self-perception of health (fair/poor/very poor or good/very good), alcohol consumption, smoking, physical activity, hospitalizations and fall (yes/no), assessment of functional capacity using the Katz Index of Independence in Activities of Daily Living (dependent, independent), self-reported morbidities such as diabetes, arterial hypertension, osteoarthritis, visual loss, depression, weight loss, cataract, glaucoma, stroke and hearing loss (yes / no).

The questionnaire was pre-tested for consistency and ease of comprehension by 10 older adults registered in the FHS program. Where deemed necessary, slight modifications were done. Next, residents were trained to collect data.

The data were organized and encoded into Excel $^{\circledR}$ and analyzed using SPSS ${ }^{\circledR}$ (Statistical Package for Social Sciences) version 17.0. Descriptive analysis was used to profile the study population. Categorical variables are presented as absolute and relative frequencies. Association between variables was tested with inferential statistics (Phi coefficient, Cramer's V-test and Kendall's tau b-test). The results were expressed in contingency tables to show trends between independent variables (sociodemographic and economic variables, clinical and health indicators and self-reported morbidities) and a dependent variable (age group). The level of significance was set at $5 \%(p<0.05)$.

This study was approved by the Research Ethics Committee of the Federal University of Triângulo Mineiro (UFTM), according to Resolution 466/12, $12 / 12 / 2012$, of the Ministry of Health (9) (protocol CEP No. 1815/11).

\section{Results}

The study population was composed of 249 older adults registered in a FHS program in the urban area of Uberaba, MG, Brazil. Table 1 shows the distribution of socioeconomic and demographic variables by age group.

As shown in Table 1, most participants were aged $60 \vdash 70$ years, married $(p<0.001)$ and had a monthly family income of $1 \dashv 3$ times the MW $(p=0.006)$. Most adults aged 80 years or older were illiterate $(\mathrm{p}<0.001)$.

Table 2 shows that older adults aged $70 \vdash 80$ years made use of $1-3$ medications ( $p=0.034)$ and that most participants aged $60 \vdash 70$ years were independent in activities of daily living (ADL) ( $p=0,004)$.

As seen in Table 3 , most participants aged $70 \vdash 80$ years had depression $(p=0.028)$, cataract $(p=0.010)$ and glaucoma $(\mathrm{p}=0.050)$.

Table 1 - Distribution of socioeconomic and demographic variables by age group. Uberaba, MG, Brazil, 2011

\begin{tabular}{|c|c|c|c|c|c|c|c|c|c|}
\hline \multirow[t]{3}{*}{ Variables } & \multicolumn{6}{|c|}{ Age group } & \multirow{2}{*}{\multicolumn{2}{|c|}{ Total }} & \multirow[t]{3}{*}{$p$-value* } \\
\hline & \multicolumn{2}{|c|}{$60 \vdash 70$} & \multicolumn{2}{|c|}{$70 \dashv 80$} & \multicolumn{2}{|c|}{80 or older } & & & \\
\hline & $n$ & (\%) & $n$ & (\%) & $n$ & (\%) & $\boldsymbol{n}^{\dagger}$ & (\%) & \\
\hline Sex & & & & & & & & & 0.342 \\
\hline Male & 53 & 39.0 & 34 & 40.0 & 6 & 22.2 & 93 & 37.5 & \\
\hline Female & 83 & 61.0 & 51 & 60.0 & 21 & 77.8 & 155 & 62.5 & \\
\hline Marital status & & & & & & & & & $<0.001^{*}$ \\
\hline Single & 10 & 7.4 & 4 & 4.8 & 3 & 11.1 & 17 & 6.9 & \\
\hline Married & 79 & 58.1 & 33 & 39.3 & 3 & 11.1 & 115 & 46.6 & \\
\hline Widowed & 30 & 22.1 & 37 & 44.0 & 19 & 70.4 & 86 & 34.8 & \\
\hline
\end{tabular}


Table 1 - Distribution of socioeconomic and demographic variables by age group. Uberaba, MG, Brazil, 2011

(Conclusion)

\begin{tabular}{|c|c|c|c|c|c|c|c|c|c|}
\hline \multirow[t]{3}{*}{ Variables } & \multicolumn{6}{|c|}{ Age group } & \multirow{2}{*}{\multicolumn{2}{|c|}{ Total }} & \multirow[t]{3}{*}{$p$-value* } \\
\hline & \multicolumn{2}{|c|}{$60+70$} & \multicolumn{2}{|c|}{$70 \dashv 80$} & \multicolumn{2}{|c|}{80 or older } & & & \\
\hline & $n$ & (\%) & $n$ & (\%) & $n$ & (\%) & $\boldsymbol{n}^{\dagger}$ & (\%) & \\
\hline Divorced & 10 & 7.4 & 7 & 8.3 & 1 & 3.7 & 18 & 4.5 & \\
\hline Consensual union & 7 & 5.1 & 3 & 3.6 & 1 & 3.7 & 11 & 4.5 & \\
\hline Education ** & & & & & & & & & $<0.001^{*}$ \\
\hline Illiterate & 20 & 14.7 & 21 & 24.7 & 10 & 37.0 & 51 & 20.6 & \\
\hline $1 \dashv 4$ & 94 & 69.1 & 61 & 71.8 & 16 & 59.3 & 171 & 69.0 & \\
\hline $4 \dashv 8$ & 13 & 9.6 & 3 & 3.5 & 1 & 3.7 & 17 & 6.9 & \\
\hline 8 or more & 9 & 6.6 & - & - & - & - & 9 & 3.6 & \\
\hline Monthly family income $* * *$ & & & & & & & & & $0.006^{\star}$ \\
\hline Up to 1 time the MW & 25 & 18.7 & 35 & 41.7 & 9 & 36.0 & 69 & 28.4 & \\
\hline $1 \vdash 3$ times the MW & 85 & 63.4 & 38 & 45.2 & 11 & 44.0 & 134 & 55.1 & \\
\hline 3 or more times the MW & 24 & 17.9 & 11 & 13.1 & 5 & 20.0 & 40 & 16.5 & \\
\hline $\begin{array}{l}\text { Responsible for household } \\
\text { expenses }\end{array}$ & & & & & & & & & 0.619 \\
\hline Yes & 120 & 88.2 & 78 & 91.8 & 25 & 92.6 & 223 & 89.9 & \\
\hline No & 16 & 11.8 & 7 & 8.2 & 2 & 7.4 & 25 & 10.1 & \\
\hline
\end{tabular}

Note: * Phi coefficient, Cramer's V-test and Kendall's tau b-test, * $p<0.05$; ** years of education; *** minimum wage of 545.00 Brazilian Reais; $\uparrow 0.9 \%$ did not answer the question.

Table 2 - Distribution of clinical and health variables by age group. Uberaba, MG, Brazil, 2011

\begin{tabular}{|c|c|c|c|c|c|c|c|c|c|}
\hline \multirow[t]{3}{*}{ Variables } & \multicolumn{6}{|c|}{ Age group } & \multirow{2}{*}{\multicolumn{2}{|c|}{ Total }} & \multirow[t]{3}{*}{$p$-value* } \\
\hline & \multicolumn{2}{|c|}{$60+70$} & \multicolumn{2}{|c|}{$70 \dashv 80$} & \multicolumn{2}{|c|}{80 or older } & & & \\
\hline & $n$ & (\%) & $n$ & (\%) & $n$ & (\%) & $\boldsymbol{n}^{\dagger}$ & (\%) & \\
\hline Self-perception of health & & & & & & & & & 0.734 \\
\hline Fair/poor/very poor & 53 & 39.6 & 37 & 44.6 & 12 & 44.4 & 102 & 41.8 & \\
\hline Good/very good & 81 & 60.4 & 46 & 55.4 & 15 & 55.6 & 142 & 58.2 & \\
\hline Morbidities & & & & & & & & & 0.890 \\
\hline None & 13 & 9.6 & 5 & 5.9 & 5 & 18.5 & 23 & 9.3 & \\
\hline 1 & 30 & 22.1 & 19 & 22.4 & 4 & 14.8 & 53 & 21.4 & \\
\hline 2 or more & 93 & 68.4 & 61 & 71.8 & 18 & 66.7 & 172 & 69.4 & \\
\hline Use of medications & & & & & & & & & $0.034^{*}$ \\
\hline None & 26 & 19.3 & 8 & 9.4 & 3 & 11.1 & 37 & 15.0 & \\
\hline $1+3$ & 60 & 44.4 & 45 & 52.9 & 6 & 37.0 & 111 & 44.9 & \\
\hline $3+5$ & 28 & 20.7 & 23 & 27.1 & 10 & 37.0 & 61 & 24.7 & \\
\hline 5 or more & 21 & 16.6 & 9 & 10.6 & 8 & 29.6 & 38 & 15.4 & \\
\hline Alcohol use & & & & & & & & & 0.165 \\
\hline Yes & 15 & 11.0 & 4 & 4.7 & 1 & 3.7 & 20 & 8.1 & \\
\hline No & 121 & 89.0 & 81 & 95.3 & 26 & 96.3 & 228 & 91.9 & \\
\hline Smoking & & & & & & & & & 0.439 \\
\hline Yes & 17 & 12.5 & 16 & 18.8 & 4 & 14.8 & 37 & 14.9 & \\
\hline No & 119 & 87.5 & 69 & 81.2 & 23 & 85.2 & 211 & 85.1 & \\
\hline
\end{tabular}


Table 2 - Distribution of clinical and health variables by age group. Uberaba, MG, Brazil, 2011

(Conclusion)

\begin{tabular}{|c|c|c|c|c|c|c|c|c|c|}
\hline \multirow[t]{3}{*}{ Variables } & \multicolumn{6}{|c|}{ Age group } & \multirow{2}{*}{\multicolumn{2}{|c|}{ Total }} & \multirow[t]{3}{*}{$p$-value } \\
\hline & \multicolumn{2}{|c|}{$60 \vdash 70$} & \multicolumn{2}{|c|}{$70 \dashv 80$} & \multicolumn{2}{|c|}{80 or older } & & & \\
\hline & $n$ & (\%) & $n$ & (\%) & $n$ & (\%) & $n^{\dagger}$ & (\%) & \\
\hline Physical exercise & & & & & & & & & 0.742 \\
\hline Yes & 33 & 24.3 & 24 & 28.2 & 6 & 22.2 & 63 & 25.4 & \\
\hline No & 103 & 75.7 & 61 & 71.8 & 21 & 77.8 & 185 & 74.6 & \\
\hline Falls & & & & & & & & & 0.114 \\
\hline Yes & 21 & 15.4 & 22 & 25.9 & 8 & 29.6 & 51 & 20.6 & \\
\hline No & 115 & 84.6 & 63 & 74.1 & 19 & 70.4 & 197 & 79.4 & \\
\hline Hospitalizations in the last 12 months & & & & & & & & & 0.268 \\
\hline Yes & 28 & 20.7 & 23 & 27.7 & 9 & 33.3 & 60 & 24.5 & \\
\hline No & 107 & 79.3 & 60 & 72.3 & 18 & 66.7 & 185 & 75.5 & \\
\hline ADL & & & & & & & & & $0.004^{*}$ \\
\hline Dependent & 4 & 2.9 & 4 & 4.7 & 5 & 18.5 & 13 & 5.2 & \\
\hline Independent & 132 & 97.1 & 81 & 95.3 & 22 & 81.5 & 235 & 94.8 & \\
\hline
\end{tabular}

Note: ${ }^{* *}$ Phi coefficient, Cramer's V-test and Kendall's tau b-test, * $p<0.05 ;$ ADL: Activities of Daily Living; †0,9\% did not answer the question.

Table 3 - Distribution of self-reported morbidities by age group. Uberaba, MG, Brazil, 2011

\begin{tabular}{|c|c|c|c|c|c|c|c|c|c|}
\hline \multirow[t]{3}{*}{ Morbidities } & \multicolumn{6}{|c|}{ Age group } & \multirow{2}{*}{\multicolumn{2}{|c|}{ Total }} & \multirow[t]{3}{*}{$p$-value* } \\
\hline & \multicolumn{2}{|c|}{$60+70$} & \multicolumn{2}{|c|}{$70 \dashv 80$} & \multicolumn{2}{|c|}{80 or older } & & & \\
\hline & $n$ & (\%) & $n$ & (\%) & $n$ & (\%) & $n^{\dagger}$ & (\%) & \\
\hline Diabetes & 25 & 18.4 & 15 & 17.6 & 4 & 14.8 & 44 & 17.7 & 0.906 \\
\hline Arterial hypertension & 82 & 60.3 & 48 & 56.5 & 18 & 66.7 & 148 & 59.7 & 0.627 \\
\hline Osteoarthritis & 47 & 34.6 & 32 & 37.6 & 13 & 48.1 & 92 & 37.1 & 0.407 \\
\hline Visual loss & 48 & 35.3 & 26 & 30.6 & 8 & 29.6 & 82 & 33.1 & 0.710 \\
\hline Depression & 15 & 11.0 & 18 & 21.2 & 1 & 3.7 & 34 & 13.7 & $0.028^{*}$ \\
\hline Weight loss & 18 & 13.2 & 21 & 24.7 & 3 & 11.1 & 42 & 16.9 & 0.060 \\
\hline Cataracts & 21 & 15.4 & 28 & 32.9 & 6 & 22.2 & 55 & 22.2 & $0.010^{*}$ \\
\hline Glaucoma & 3 & 2.2 & 8 & 9.4 & 1 & 3.7 & 12 & 4.8 & $0.050^{*}$ \\
\hline Stroke & 6 & 4.4 & 4 & 4.7 & 1 & 3.7 & 11 & 4.4 & 0.976 \\
\hline Hearing loss & 19 & 14.0 & 18 & 21.2 & 8 & 29.6 & 45 & 18.1 & 0.104 \\
\hline
\end{tabular}

Note: * Cramer's V test, ${ }^{\star} p<0.05$.

\section{Discussion}

Knowledge of older adults' characteristics contribute to the performance of health promotion and damage prevention actions, as well as to the implementation of appropriate public policies targeted at improving the health of this population (10). Many health interventions have been implemented in Brazilian municipalities to promote active aging and improve ADL, socialization, independence and quality of life. One of such interventions is the Third-Age Gym (Academia da Terceira Idade, ATI), which offers many benefits from guided regular physical activity. In Uberaba, 75\% of Third-Age Gym goers are female and $25 \%$ are male. The ATI provides motivation to the adoption of more active and healthy lifestyles (11). 
The socioeconomic characteristics of older adults found in this study are consistent with the data from the National Household Sample Survey (PNAD) (12) and other studies $(13,14)$.

The predominance of females in these studies supports the existence of the phenomenon of feminization of old age, as women are more concerned about health, can better explain their symptoms and seek health care more frequently than men. These results reaffirm the findings of Leal et al. (15). It is important to encourage and instruct the aged population to participate in alternative programs aimed at health promotion and disease prevention such as the Universities Open to the third-age population (Universidades Abertas à Terceira Idade, UnATIs) and the ATI $(11,16)$.

The high mortality rate in the male population is especially due to external causes, such asviolence and accidents, and affects mainly younger individuals (12). Since external causes are preventable, many actions have been implemented to reduce related deaths. In Brazil, such actions are designed through policy measures such as the Política Nacional de Redução da Morbimortalidade por Acidentes e Violência and implemented through shared responsibility between managers and the society (17). Health professionals should provide advice, disseminate and raise public awareness of policy guidelines.

Although the findings of some studies $(14,18)$ coincide that most older adults are married, the general trend is that this reality changes. According to the 2010 Demographic Census (19), the number of single-person households has been constantly increasing between censuses. Moreover, as shown by Farias \& Santos (20), most widowed people are older than 80 years. When added to lowliness, high morbidity levels, neglect of self-care, lack of care, safety risks and financial difficulties may hamper coping processes and have a negative impact on quality of life (21). Thus, interventions from interdisciplinary teams are important to promote the systematization of education, guidance and support actions to older adults.

In line with other studies, in this study there was a higher percentage of illiterates in the age group 80 years or over $(10,13)$. According to the PNAD $(12)$, the illiteracy rate increases with age. The high illiteracy rates among this population may be linked to the difficulties of access to school, dropout, length of stay and educational performance in literacy (22).
These results are extremely important, because education interferes with proper use of medications, adherence to prescribed treatment, self-care and quality of life $(23,24)$.

A determining factor in the health status of older adults is family income. When associated with education, it can compromise the autonomy and independence of older adults (14). The results obtained by Neri et al. (18) in four Brazilian cities corroborate the findings of this study. For many people, retirement - a fixed income guarantee represents improvements in living conditions. For this reason, the (Brazilian) National Policy on Health Care for the Elderly (3) creates and encourages the development of retirement preparation programs and provides an array of mechanisms to prevent discrimination against older people in employment. This governmental policy is relevant because working to advanced ages, having an occupation, participation in social and leisure activities promote the maintenance of functional capacity and lead to better quality of life $(12,25)$.

In this study, approximately $90 \%$ of older adults were responsible for household expenses. This corroborates the findings of a study conducted in two Brazilian cities, namely Parnaíba and Campina Grande (18). According to the PNAD (12), in the last 10 years, there has been a significant increase in the proportion of female heads of family. Being responsible for household expenses reflects the prioritization of relatively high expenditures on food, housing and transportation, and limited access to health insurances and sources of well-being, which affects quality of life.

Regardless of age group, more than $70 \%$ of older adults reported not having experienced any falls in the last 12 months. In the study by Chianca et al. (26), only about $41 \%$ of participants reported the same. On the other hand, Brito et al. (27) found that $27.7 \%$ of long-lived older adults self-reported falls. According to Nascimento \& Tavares, falls are associated with longevity and having two or more morbidities is their greatest predictor (28). The occurrence of falls has been associated with increasing age. It leads to losses in functional status and is considered a major public health problems (27). Interdisciplinary interventions are relevant strategies for older adults' maintenance, promotion or recovery of autonomy and independence, as they assess neuromotor and psychosocial aspects that interfere with and are related to aging (29). 
Seventy-five percent of older adults reported not having been hospitalized in the last 12 months. This could lead to functional decline and cause a greater impact in the lives of both older adults and their family members (30). According to the Center for Education in Collective Health (Núcleo de Educação em Saúde Coletiva, NESCON) (31), in all Brazilian regions, there was a drop in the number of hospitalizations due to conditions sensitive to primary care (ICSAP) in the Unified Health System. The NESCON also claims that primary care programs should be adapted to include strategies for reducing hospitalizations. Programs such as Home Hospitalization (Internação Domiciliar) (32) and Hiperdia (33) (for patients with hypertension and diabetes) contribute to this goal.

There were also similar results relating to perception of health.in all age groups. Fifty-five to 60 percent of participants had positive perceptions of their health. These results corroborate the findings of Silva et al. (34), who found a percentage of $51 \%$. In most older adults, a positive self-assessment of health may be linked to independence and lack of hospitalizations and falls (35). According to Bittar \& Lima (36), group activities help in the recovery of forgotten values and feelings, social interaction, and daily live motivation, and improve self-esteem and health, promoting overall quality of life in old age.

According to the PNAD (12), 75\% of older adults reported having one chronic disease, and 64\% reported having two or more diseases. Both the presence of comorbidities and the use of medications were more prevalent among older adults aged 70-80 years. Concomitant use of medications makes older adults more susceptible to drug interactions that can lead to serious consequences and permanent damage (37). Hence, to protect older adults, permanent monitoring by a specialized team that provides clear advice on proper use of medication and active participation of a caregiver are essential (37).

The highest percentages of non-smokers, nondrinkers and non-physically active older adults were found among octogenarians. There was, however, no statistically significant difference between groups. Physical inactivity leads to functional decline, cognitive deficit, gait alterations and, consequently, to a greater risk of falls and dependence. Interventions for the promotion and encouragement of physical exercise to improve strength, flexibility and balance, and reduce falls are of paramount importance and can contribute to reduce functional decline (38).
Regular physical activity has been considered to be a way to maintain physical fitness in older adults, as it may delay age-related processes and contribute to preserve functional autonomy and quality of life $(11,38)$.

According to Brito et al. (27), there is a link between age and loss of independence. The authors have shown that $19.6 \%$ of long-lived older adults had higher levels of dependence in ADL. This is in line with the findings of this study, in which $18.5 \%$ of longlived older adults had higher levels of dependence. The loss in functional independence experienced by adults in this age group may be explained by their low education and income (25).

As already shown by Clares et al. (14), arterial hypertension is the most prevalent disease among older adults. It makes them vulnerable to cardiac and cerebrovascular complications and can lead to disabilities and death. The participation of interprofessional teams in Hiperdia programs is extremely important, because the program promotes adherence to pharmacological and nonpharmacological treatment, reduction of disease complications and prevention and control of arterial hypertension and diabetes (33).

The highest prevalence of depression, cataract and glaucoma was found among older adults aged $70 \vdash 80$ years. A study conducted with older adults registered in a FHS program in Dourados, Brazil, found that participants with depression had poor housing conditions and low income, were physically inactive, did not participate in social activities and self-assessed their health as "poor" (13). Depression may also be an indicative of future physical functional disability in people with mobility impairments (39). Nunes et al. (25) found that $64.4 \%$ of older adults had impaired visual acuity. Visual deficiencies are highly prevalent in older adults and represent a potential risk of falls and injuries. They can lead to dependency, reduced quality of life and increased public costs $(27,40)$.

Hence, a comprehensive approach to the population registered in the FHS program, based on the real health status of older adults and family members favors the implementation of more customized health care interventions to older adults.

Some limitations of this study were: the crosssectional design, which does not allow inference of causality; the impossibility of setting a predetermined time for data collection, which led to losses to the study population population (as participants could 
not be found at home on repeated visits); and the non-use of cognitive assessment tests prior to the interviews to control for answer reliability. However, the data from interviewees with apparent cognitive impairment were discarded.

\section{Conclusion}

Socioeconomic and health status were associated with age groups. Of note, there was a higher prevalence of medication use and morbidities among older adults aged 70-79 years and a greater number of illiterates in the age group 80 years or older.

The knowledge of these characteristics helps FHS team members to implement more accurate and customized strategies and interventions to deliver more effective and efficient care to older adults. Moreover, participation in a multiprofessional team provides an interdisciplinary learning and work experience for health professionals.

\section{References}

1. Veras R. Envelhecimento populacional: desafios e inovações necessárias para o setor saúde. Med HUPEUERJ. 2008;7(1):13-20.

2. Veras R. Envelhecimento populacional contemporâneo: demandas, desafios e inovações. Rev Saude Publica. 2009;43(3):548-54.

3. Brasil. Portaria n⿳0 2.528, de 8 de outubro de 2006. Aprova a Política Nacional de Saúde da Pessoa Idosa. [cited 2014 Apr 11]. Available at: https://tinyurl.com/ ybdl6a8q.

4. Brasil. Portaria Interministerial $\mathrm{n}^{-} \mathbf{1 . 0 7 7}$, de 12 de novembro de 2009. Dispõe sobre a Residência Multiprofissional em Saúde e a Residência em Área Profissional da Saúde e institui o Programa Nacional de Bolsas para Residências Multiprofissionais e em Área Profissional da Saúde e a Comissão Nacional de Residência Multiprofissional em Saúde.

5. Silvestre JA, Costa Neto MM. Abordagem do idoso em programas de saúde da família. Cad Saude Publica. 2003;19(3):839-47.
6. Brasil. Ministério da Saúde. Secretaria de Atenção à Saúde. Departamento de Atenção Básica. SIAB: manual do sistema de Informação de Atenção Básica. 1st ed. Brasília: MS; 2003.96 p.: il. - (Série A. Normas e Manuais Técnicos).

7. Brasil. Secretaria de Estado de Saúde. Atenção á saúde do idoso. Belo Horizonte: SAS/MG; 2006. 186 p.

8. Brasil. Ministério da Saúde. Caderneta de Saúde da pessoa idosa. Brasília; 2007.

9. Brasil. Ministério da Saúde (MS). Conselho Nacional de Saúde. Resolução no 466, de 12 de dezembro de 2012. Diário Oficial da União 2013; 13 dez.

10. Marin MJS, Bazaglia FC, Massarico AR, Silva CBA, Campos RT, Santos SC. Características sóciodemográficas do atendimento ao idoso após alta hospitalar na Estratégia da Saúde de Família. Rev Esc Enferm. 2010:44(4):962-8.

11. Silva de Paulo TR, Castellano SM, Queiroz Jr CA, Freitas Jr IF. Programa Academia da Terceira Idade no município de Uberaba, MG. Arq Cien Esp. 2012;1(1):54-9.

12. Instituto Brasileiro de Geografia e Estatística (IBGE). Síntese de Indicadores Sociais. Uma análise das condições de vida da população brasileira. Rio de Janeiro; 2012.

13. Alvarenga MRM, Oliveira MAC, Faccenda O, Sousa RA. Perfil Social e Funcional de idosos assistidos pela Estratégia da Saúde da Família. Cogitare Enferm. 2011;16(3): 478-85.

14. Clares JW, Freitas MC, Almeida PC, Galiza FT, Queiroz TA. Perfil de idosos cadastrados numa Unidade Básica de Saúde da Família de Fortaleza-CE. Rev Rene. 2011;12(n. esp.): 988-94.

15. Leal MCC, Marques APO, Marino JG, Rocha EC, Santos CR, Austregésilo SC. Perfil de pacientes idosos e tempo de permanência em ambulatório geronto-geriátrico. Rev Bras Geriatr Gerontol. 2009;12(1):77-86.

16. Oliveira DC, Simoneau AS. Os programas universitários para as pessoas idosas (UnATIs): um estudo de representação social. Estud Pesqui Psicol. 2012;12(2):446-61. 
17. Brasil. Ministério da Saúde. Secretaria de Vigilância em Saúde. Departamento de Análise de Situação de Saúde. Portaria MS/GM n. ${ }^{\circ} 737$ de 16/5/01. Aprova a Política nacional de redução da morbimortalidade por acidentes e violências. 2nd ed. Brasília: Editora do Ministério da Saúde; 2005. 64 p. - (Série E. Legislação de Saúde).

18. Neri AL, Yassuda MS, Araújo LF, Eulálio MC, Cabral BE, Siqueira MEC. Metodologia e perfil sociodemográfico, cognitivo e de fragilidade de idosos comunitários de sete cidades brasileiras: Estudo FIBRA. Cad Saude Publica. 2013;29(4),778-92.

19. Brasil. Ministério do Planejamento, Orçamento e Gestão. Instituto Brasileiro de Geografia e Estatística - IBGE. Censo Demográfico 2010. Características da população e dos domicílios. Resultados do universo. Rio de Janeiro; 2011.

20. Farias RG, Santos SMA. Influência dos determinantes do envelhecimento ativo entre idosos mais idosos. Texto Contexto Enferm. 2012;21(1):167-76.

21. Ramos JLC, Menezes MR, Meira EC. Idosos que moram sozinhos: desafios e potencialidades do cotidiano. Rev Baiana de Enferm. 2010;24(1,2,3):43-54.

22. Brasil. Presidência da República, Observatório da Equidade. As Desigualdades na Escolarização no Brasil. Brasília: Presidência da República, Observatório da Equidade; 2009.

23. Silva LWS, Santos KMO. Analfabetismo e declínio cognitivo: um impasse para o uso adequado de medicamentos em idosos no contexto familiar. RKG. 2010;13(1):245-57.

24. Marques MB, Silva MJ, Coutinho JFV, Lopes MVO. Avaliação da competência de idosos diabéticos para o autocuidado. Rev Esc Enferm. 2013;47(2):415-20.

25. Nunes MCR, Ribeiro CL, Rosado LEFL, Franceschini SC. Influência das características sociodemográficas e epidemiológicas na capacidade funcional de idosos residentes em Ubá, Minas Gerais. Rev Bras Fisioter. 2009;13(5):376-82.
26. Chianca TCM, Andrade CR, Albuquerque J, Wenceslau LCC, Ribeiro Tadeu LF, Macieira TGR, et al. Prevalência de quedas em idosos cadastrados em um Centro de Saúde de Belo Horizonte-MG. Rev Bras Enferm. 2013;66(2):234-40.

27. Brito TA, Fernandes MH, Coqueiro RS, Jesus CS. Quedas e Capacidade Funcional em idosos Longevos residentes em comunidade. Texto Contexto Enferm. 2013;22(1):43-51.

28. Nascimento, JS, Tavares DMS. Prevalência e fatores associados a quedas em idosos. Texto Contexto Enferm. 2016;25(2):1-9.

29. Schneider ARS. Envelhecimento e quedas: a fisioterapia na promoção e atenção à saúde do idoso. RBCEH. 2010;7(2):296-303.

30. Menezes C, Oliveira VRC, Menezes RL. Repercussões da Hospitalização na capacidade funcional de idosos. Rev Mov. 2010 3(2):76-84.

31. Núcleo de Educaçâo em Saúde Coletiva - NESCON. Avaliação do Impacto das Ações do Programa de Saúde da Família na Redução das Internações Hospitalares por Condições Sensíveis à Atenção Básica em Adultos e Idosos. Belo Horizonte: Universidade Federal de Minas Gerais; 2012.

32. Martelli DRB, Silva MS, Carneiro JA, Bonan PRF, Rodrigues LHC, Martelli-Júnior H. Internação domiciliar: o perfil dos pacientes assistidos pelo Programa HU em Casa. Physis. 2011;21(1):147-57.

33. Lima AS, Gaia ESM, Ferreira MA. A importância do Programa Hiperdia em uma Unidade de Saúde da Família do município de Serra Talhada - PE, para adesão dos hipertensos e diabéticos ao tratamento medicamentoso e dietético. Rev Saúde Coletiva em Debate. 2012;2(1):30-29.

34. Silva RJS, Smith-Menezes A, Tribess S, Rómo-Perez V, Virtuoso Jr JS. Prevalência e fatores associados à percepção negativa da saúde em pessoas idosas no Brasil. Rev Bras Epidemiol. 2012;15(1):49-62. 
35. Pagotto V, Bachion MM, Silveira EA. Autoavaliação da saúde por idosos brasileiros: revisão sistemática da literatura. Rev Panam Salud Publica. 2013;33(4):302-10.

36. Bittar C, Lima LCV. O impacto das atividades em grupo como estratégia de promoção da saúde na senescência. RKG. 2011;14(4):101-18.

37. Giacomin MS, Lima ATF, Chaves ACP. Perfil da farmacoterapia de idosos institucionalizados de uma cidade no Vale do Aço - MG. Farmácia \& Ciência. 2012;3:1-19.

38. Fernandes AMBL, Ferreira JJA, Stolt LROG, Brito GEG, Clementino ACCR, Sousa NM. Efeitos da prática de exercício físico sobre o desempenho da marcha e da mobilidade funcional em idosos. Fisioter Mov. 2012;25(4):821-30.
39. Lêng $\mathrm{CH}$, Wang JD. Long term determinants of functional decline of mobility: An 11-year follow-up of 5464 adults of late middle aged and elderly. Arch Gerontol Geriatr. 2013;57(2):215-20.

40. Reed-Jones RJ, Solis GR, Lawson KA, Loya AM, Cude-Islas D, Berger CS. Vision and falls: A multidisciplinary review of the contributions of visual impairment to falls among older adults. Maturitas. 2013;75(1):22-8.

Received in $05 / 14 / 2016$

Recebido em 14/05/2016

Approved in 04/03/2017

Aprovado em 03/04/2017 